Studia Kinanthropologica, XXII, 2021, (2-3), 115-122

The Scientific Journal for Kinanthropology

doi: $10.32725 /$ sk.2021.009

\title{
VZŤAH MEDZI JEDNOTLIVÝMI DISCIPLÍNAMI A ŠPORTOVÝM VÝ- KONOM V TRIATLONE
}

\section{THE RELATIONSHIP BETWEEN INDIVIDUAL DISCIPLINES AND SPORTS PERFORMANCE IN TRIATHLON}

\author{
L. Odráška, ${ }^{1}$ H. Kr $\check{c}^{2} \&$ K. Filipová ${ }^{3}$ \\ ${ }^{1}$ Trnavská Univerzita v Trnave, Pedagogická fakulta, Katedra školskej pedagogiky \\ ${ }^{2}$ Univerzita Komenského v Bratislave, Lekárska fakulta, Ústav telesnej výchovy a športu \\ ${ }^{3}$ Stredná športová škola, Nitra
}

\begin{abstract}
The aim of the work was to find out what is the relationship between individual disciplines and the overall performance in triathlon. For the analysis, we used the results of three top events for each variant of triathlon for the years 2019 to 2021. The analyzed consisted of athletes in the elite category. We analyzed the sprint triathlon, the Olympic triathlon, the long triathlon and the off-road triathlon. We used Spearman's correlation coefficient to verify the relationships between the individual variables. Results: For all monitored triathlons, we observed statistically significant relationships $(\mathrm{p}<0,05)$ for running, with the most significant contribution to the overall result in Olympic $(\mathrm{R}=0,907 ; 0,840$; $0,964)$ and long men's triathlon $(\mathrm{R}=0,832 ; 0,772 ; 0,878)$. For cycling, we observed statistically significant relationships $(\mathrm{p}<0,01)$ in all but one of the triathlons monitored, with cycling most significantly contributing to the overall result in the off-road triathlon of men $(\mathrm{R}=0,932 ; 0,896$; $0,961)$, women $(\mathrm{R}=0,946 ; 0,826 ; 0,875)$ and in women's long triathlon $(\mathrm{R}=0,879 ; 0,706 ; 0,864)$. For the men's sprint triathlon, we observed the most significant correlations twice for running $(\mathrm{R}=0,965$; $0,849)$ and once for cycling $(R=0,873)$. Women in the sprint, similarly to men, were dominated twice by running $(\mathrm{R}=0,885 ; 0,820)$ and once by cycling $(\mathrm{R}=0.895)$. For the women's Olympic Triathlon, we recorded the strongest correlation for running $(R=0,827 ; 0,828)$ and once for cycling $(R=0,907)$.
\end{abstract}

Keywords: triathlon; performance; analysis

\section{Súhrn}

Ciel’om práce bolo zistit', aký je vzt’ah medzi jednotlivými disciplínami a celkovým výkonom v triatlone. $\mathrm{K}$ analýze sme použili výsledky z troch vrcholných podujatí pre každú variantu triatlonu za roky 2019 až 2021. Analyzovanú vzorku tvorili pretekári a pretekárky kategórie elite. Sledovali sme šprint triatlon, olympijský triatlon, dlhý triatlon a terénny triatlon. Na overenie vztahov medzi jednotlivými premennými sme použili Spearmanov korelačný koeficient. Výsledky: Pre všetky sledované triatlony sme pozorovali štatisticky významné vzt’ahy $(\mathrm{p}<0,05)$ pre beh, pričom najvýraznejšie sa podiel'a na celkovom výsledku v olympijskom $(\mathrm{R}=0,907 ; 0,840 ; 0,964)$ a dlhom triatlone mužov $(\mathrm{R}=0,832 ; 0,772$; 0,878). Pre cyklistiku sme pozorovali štatisticky významné vztahy $(\mathrm{p}<0,01)$ vo všetkých sledovaných triatlonoch okrem jedného, pričom najvýraznejšie sa cyklistika podiel'ala na celkovom výsledku v terénnom triatlone mužov $(\mathrm{R}=0,932 ; 0,896 ; 0,961)$, žien $(\mathrm{R}=0,946 ; 0,826 ; 0,875)$ a v dlhom triatlone žien $(\mathrm{R}=0,879 ; 0,706 ; 0,864)$. Pre šprint triatlon mužov sme najvýznamnejšie korelácie zaznamenali dva krát pre beh $(\mathrm{R}=0,965 ; 0,849)$ a raz pre cyklistiku $(\mathrm{R}=0,873)$. U žien v šprinte, podobne ako u mužov, dominoval dva krát beh $(\mathrm{R}=0,885,0,820)$ a raz cyklistika $(\mathrm{R}=0,895)$. Pre olympijský triatlon žien sme zaznamenali najvýraznejšiu koreláciu pre beh $(\mathrm{R}=0,827 ; 0,828)$ a raz pre cyklistiku $(\mathrm{R}=0,907)$.

Kl’účové slová: triatlon; výkon; vzt’ahová analýza 


\section{Úvod}

Formánek \& Horčič, (2003) definujú triatlon ako vytrvalostný viacboj a multišport, ktorý kombinuje tri športy: plávanie, cyklistiku a beh v ich vytrvalostnej podobe. Charakteristická požiadavka na výkon je špeciálna vytrvalost' športovca, ktorá je potrebná na vyrovnanie sa s meniacou sa intenzitou a charakterom zat’aženia počas pretekov. Samotný výkon začína okamihom štartu a končí prebehom ciel'ovej čiary, pričom triatlonista absolvuje disciplíny bezprostredne za sebou a v presne stanovenom poradí. Medzi disciplínami sa musí pretekár zastavit’ v depe, kde po plávaní zanecháva už nepotrebné plavecké pomôcky a vybaví sa pomôckami na bicykel a následne po cyklistike na bežeckú čast'. Medzinárodná triatlonová únia (ITU) rozdel’uje triatlon do štyroch hlavných kategórií (tab. 1). V športovej praxi sa stretávame aj s tzv. stredným triatlonom, ktorý sa realizuje na polovičných vzdialenostiach dlhého triatlonu. Podiel jednotlivých častí je pre jednotlivé triatlony rozdielny (tab. 2). Z celkového času v cieli je však pre všetky varianty dominantná cyklistika, nasledovaná behom a najnižší podiel na celkovom čase má plávanie. Prechody medzi jednotlivými častami (z anglického transition - T) tvoria menej ako $2 \%$ z celkového času.

Tabul'ka 1./ Table 1.

Rozdelenie triatlonov podl'a vzdialenosti./ Competition distances (World Triathlon Competition Rules 2020).

\begin{tabular}{cccc}
\hline Triatlon/ Triathlon & $\mathrm{km}$ & $\mathrm{km}$ & $\mathrm{km}$ \\
\hline Sprint/ Sprint & 0,75 & 20 & 5 \\
Olympijský / Olympic & 1,5 & 40 & 10 \\
Dlhý/ Long & 3,8 & 180 & 42 \\
Terénny/ Cross & $0,75-1,9$ & $20-90$ & $5-21$ \\
\hline
\end{tabular}

Tabul'ka 2./ Table 2.

Priemerný podiel jednotlivých častí triatlonu na celkovom čase v nami sledovaných triatlonoch./ The average proportion of individual parts of the triathlon in the total time in the triathlons we monitor.

\begin{tabular}{cccccc}
\hline Triatlon/ Triathlon & Plávanie & T1 & Bicykel & T2 & Beh \\
\hline Spprint/ Sprint & $18,00 \%$ & $1,57 \%$ & $50,22 \%$ & $0,65 \%$ & $30,00 \%$ \\
Olympijský/ Olympic & $15,00 \%$ & $0,59 \%$ & $50,00 \%$ & $1,00 \%$ & $36,00 \%$ \\
Dlhý/ Long & $10,72 \%$ & $0,57 \%$ & $52,70 \%$ & $0,55 \%$ & $35,77 \%$ \\
Terénny/ Cross & $14,86 \%$ & $0,54 \%$ & $58,35 \%$ & $0,44 \%$ & $26,25 \%$ \\
\hline
\end{tabular}

Špecifikum triatlonu je, že pre jednotlivé vzdialenosti neplatia jednotné pravidlá. Podl’a pravidiel medzinárodnej triatlonovej únie je jazda v zákryte (tzv. drafting) za iným jazdcom povolená pre šprint, olympijský a terénny triatlon. Pre dlhý triatlon je jazda v zákryte zakázaná. Predpokladáme preto, že vzt’ah medzi jednotlivými disciplínami a výsledným časom pre rôzne varianty triatlonu budú rozdielne. Vzt’ahom medzi jednotlivými častami triatlonu a celkovým výsledkom sa zaoberali mnohé štúdie (Schuylenbergh, Eynde \& Hespel, 2004; Figueiredo, Marques \& Lepers, 2016; Millet \& Vleck, 2000; Horne, 2017; Cejuela et al., 2013; Sousa et al., 2021) a dospeli k rôznym záverom. Pre vzdialenosti šprint triatlonu Horne (2017) poukazuje na to, že na svetovom šampionáte, kde boli športovci rozdelení podl'a vekových skupín, mala cyklistika najsilnejší vzt’ah k celkovému času, zatial' čo najnižšia korelácia s časom v cieli bola zistená v plaveckej časti. Rovnako tak Sousa et al., (2021) tvrdia, že najlepším prediktorom výsledku v šprinte je cyklistika. Pokial ide o bežeckú čast, tí istí autori dospeli k záveru, že dôležitost’ behu v predikcii celkového výkonu klesá s klesajúcou vzdialenostou pretekov. Olaya et al., (2021) skúmali vzt’ah jednotlivých segmentov šprint triatlonu a celkovým výsledkom. Autori sledovali oficiálne výsledky z podujatí svetovej triatlonovej série v rokoch 2012 až 2019. Celkovo bolo sledovaných 2144 záznamov, z toho 1143 mužov a 1001 žien. K analýze autori použili vnútrotriedny korelačný koeficient ICC. Výsledky preukázali, že výkon v cyklistickom segmente predstavoval najlepšiu zhodu s celkovým výkonom u elitných mužov (ICCa $=0,871, \mathrm{IC} 95 \%=(0,711$ - 0,927)) a elitných žien $(\mathrm{ICCa}=0,907, \mathrm{IC} 95 \%=(0,875-0,929))$. V rozpore s tým je štúdia autorov 
Schuylenbergh, Eynde \& Hespel, (2004), kde autori uvádzajú, že bežecká čast’ by mala byt’ primárnym determinantom úspechu v triatlonoch na krátkych tratiach v kategórií elite; treba však poznamenat', že tento výskum bol realizovaný na študentoch telesnej výchovy. Napriek tomu boli podobné výsledky pozorované na olympijskej vzdialenosti (Sousa et al., 2021). Pri olympijskom triatlone Cejuela et al., (2021) sledovali korelácie pre všetky časti triatlonu vrátene času medzi prechodmi plávanie - cyklistika, cyklistika - beh. Percentá celkového času zodpovedajúceho každej časti pretekov boli: 16,2\% plávanie; $0,74 \%$ pri prechode medzi plávaním a cyklistikou (T1); $53,07 \%$ cyklistika; 0,47\% pri prechode medzi cyklistikou a behom (T2 ) a 29,5\% beh. Korelácie medzi každou častou pretekov a konečným umiestnením boli: $\mathrm{r}=0,36$ pre plávanie, $\mathrm{r}=0,25$ pre $\mathrm{T} 1, \mathrm{r}=0,62$ pre cyklistiku, $\mathrm{r}=0,33$ pre T2 a $\mathrm{r}=0,83$ pre beh. Pre dlhý triatlon sledovali korelácie medzi jednotlivými častami triatlonu a celkovým výsledkom Sousa et al., (2021). Disciplínou s najväčším podielom na celkovom čase pretekov bola cyklistika $(54,13 \% \pm 1,06)$, ktorú nasledoval beh $(34,83 \% \pm 1,02)$, plávanie $(10,20 \% \pm 0,64)$ a súčtom časov prechodu $(0,84 \% \pm 0,18)$. Korelácie pre jednotlivé disciplíny a výsledný čas boli nasledovné: $\mathrm{r}=0,327$ pre plávanie; $\mathrm{r}=0,520$ pre cyklistiku a $\mathrm{r}=0,151$ pre beh. Pre terénny triatlon sa koreláciou medzi jednotlivými disciplínami a celkovým výsledkom zaoberal Hurst (2018), pričom sledoval koreláciu jednotlivých disciplín terénneho triatlonu a celkového výsledku v sútłaži. Pre mužov boli výsledky: plávanie $-\mathrm{R}_{2}=0,17$; cyklistika $-\mathrm{R}_{2}=0,31$; beh $-\mathrm{R}_{2}=0,16$. Pre ženy boli výsledky: plávanie $\mathrm{R}_{2}=0,15$; cyklistika $-\mathrm{R}_{2}=0,26$ a beh $-\mathrm{R}_{2}=0,46$. Pre rôzne disciplíny triatlonu môžeme pozorovat' rôzne výsledky korelačných analýz, pričom najčastejšie pozorujeme najvýznamnejší vztah s celkovým výsledkom pre cyklistiku. Ciel'om práce bolo zistit', aký je vztłah medzi jednotlivými disciplínami a celkovým výkonom v triatlone v roku 2021.

\section{Metodika}

Sledovaný súbor tvorili muži a ženy kategórie elite. Analyzovali sme výsledky z vrcholných podujatí (tab. 3), ktoré sme získali zo stránky www.triathlon.org. Sledovali sme dosiahnuté časy v jednotlivých disciplínach triatlonu (plávanie, cyklistika, beh), čas strávený v prechodnej časti (T1;T2) po plávaní a cyklistike a celkový čas pretekára v cieli. Sledovali sme MS - majstrovstvá sveta; ME - majstrovstvá Európy; WC - svetový pohár a EC - európsky pohár. Celkovo sme spracovali 3 podujatia pre každú verziu triatlonu pre obe pohlavia. Snažili sme sa tak čiastočne eliminovat’ vplyv počasia, profilu trate prípadne taktiky na sledované parametre. Získané empirické údaje sme podrobili matematicko štatistickému spracovaniu s využitím počítačového programu Microsoft Office Excel 2016 (Microsoft Corporation, Washington - USA) a IBM SPSS Statistics 25 (IBM, Armonk, NY - USA). Na overenie normality rozloženia dát sme použili Shapiro-Wilk test. K analýze vzt’ahov medzi jednotlivými častami triatlonu a celkovým výsledkom sme na základe výsledkov testu normality rozloženia dát použili Spearmanov korelačný koeficient, interpretovaný podl'a Chrásku, 2007.

\section{Výsledky}

Získané výsledky pre jednotlivé pohlavie a disciplínu uvádzame v tabul'ke č. 3 až č. 8 .

Tabul'ka 3./ Table 3.

Korelácie pre šprint triatlon muži./ Correlation for sprint triathlon men.

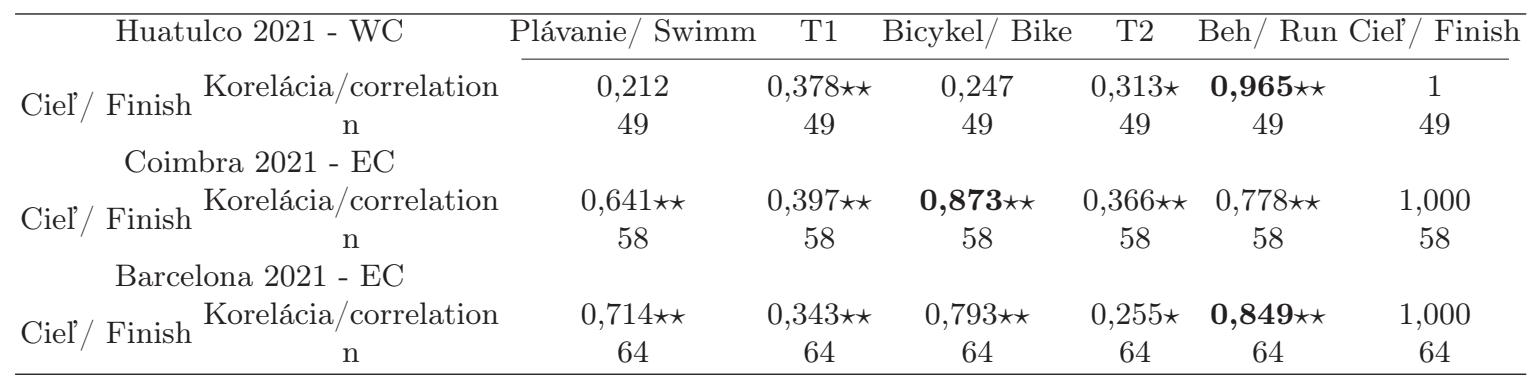

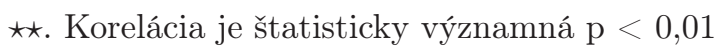

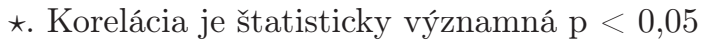


Tabul'ka 4./ Table 4.

Korelácie pre olympijský triatlon muži./ Correlation for olympic triathlon men.

\begin{tabular}{|c|c|c|c|c|c|c|}
\hline Valencia 2021 - ECH & Plávanie/ Swimm & $\mathrm{T} 1$ & Bicykel/ Bike & $\mathrm{T} 2$ & Beh/ Run & Ciel'/ Finish \\
\hline Ciel'/ Finish $\frac{\text { Korelácia/correlation }}{\mathrm{n}}$ & $\begin{array}{c}0,385 \star \star \\
50\end{array}$ & $\begin{array}{c}0,421 \star \star \\
50\end{array}$ & $\begin{array}{c}0,397 \star \star \\
50\end{array}$ & $\begin{array}{c}0,351 \star \\
50\end{array}$ & $\begin{array}{c}\mathbf{0 , 9 0 7} \star \star \\
50\end{array}$ & $\begin{array}{c}1,000 \\
50\end{array}$ \\
\hline $\begin{array}{c}\text { Karlovy Vary } 2021 \text { - WC } \\
\text { Ciel'/ Finish Korelácia/correlation } \\
\text { n }\end{array}$ & $\begin{array}{c}0,461 \star \star \\
53\end{array}$ & $\begin{array}{c}0,209 \\
53\end{array}$ & $\begin{array}{c}0,836 \star \star \\
53\end{array}$ & $\begin{array}{c}-0,446 \star \star \\
53\end{array}$ & $\begin{array}{c}\mathbf{0 , 8 4 0} \star \star \star \\
53\end{array}$ & $\begin{array}{c}1,000 \\
53\end{array}$ \\
\hline $\begin{array}{c}\text { Lisbon 2021 - WC } \\
\text { Ciel'/ Finish Korelácia/correlation } \\
\text { n }\end{array}$ & $\begin{array}{c}0,237 \\
54\end{array}$ & $\begin{array}{c}0,262 \\
54\end{array}$ & $\begin{array}{c}0,006 \\
54\end{array}$ & $\begin{array}{c}0,316 \star \\
54\end{array}$ & $\begin{array}{c}\mathbf{0 , 9 6 4} \star \star \star \\
54\end{array}$ & $\begin{array}{c}1,000 \\
54\end{array}$ \\
\hline
\end{tabular}

$\star \star$. Korelácia je štatisticky významná p $<0,01$

*. Korelácia je štatisticky významná p $<0,05$

Tabul'ka 5./ Table 5 .

Korelácie pre dlhý triatlon muži./ Correlation for long triathlon men.

\begin{tabular}{ccccccc}
\hline Amsterdam 2021 - MS & Plávanie/ Swimm & T1 & Bicykel/ Bike & T2 & Beh/ Run Ciel' / Finish \\
\cline { 2 - 7 } Ciel'/ Finish Korelácia/correlation & $0,574 \star \star$ & 0,269 & $0,683 \star \star$ & $0,607 \star \star$ & $\mathbf{0 , 8 3 2 \star \star}$ & 1 \\
n & 26 & 26 & 26 & 26 & 26 & 26 \\
Roth 2021 - ME & & & & & & \\
Ciel'/ Finish Korelácia/correlation & $0,542 \star$ & 0,099 & $0,660 \star \star$ & 0,339 & $\mathbf{0 , 7 7 2 \star \star}$ & 1,000 \\
n & 19 & 19 & 19 & 19 & 19 & 19 \\
Amsterdam 2019 - ME & & & & & & \\
Ciel'/ Finish Korelácia/correlation & 0,386 & $0,443 \star$ & $0,800 \star \star$ & $0,544 \star$ & $\mathbf{0 , 8 7 8 \star \star}$ & 1,000 \\
$n$ & 21 & 21 & 21 & 21 & 21 & 21 \\
\hline
\end{tabular}

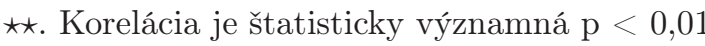

*. Korelácia je štatisticky významná p $<0,05$

Tabul'ka 6./ Table 6 .

Korelácie pre terénny triatlon muži./ Correlation for cross triathlon men.

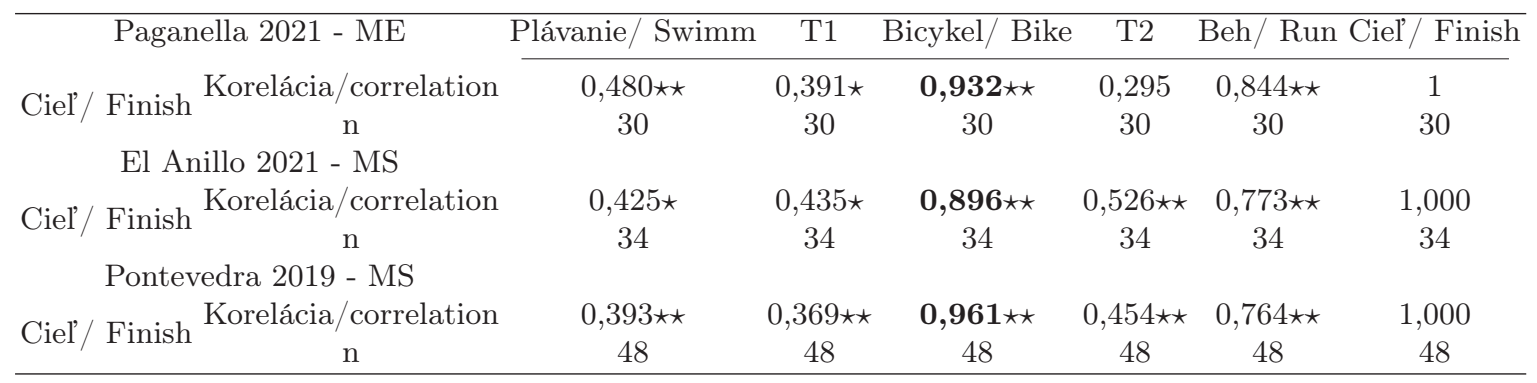

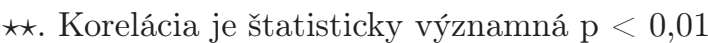

*. Korelácia je štatisticky významná p $<0,05$ 
Tabul'ka 7./ Table 7.

Korelácie pre šprint triatlon ženy./Correlation for sprint triathlon women.

\begin{tabular}{|c|c|c|c|c|c|c|c|}
\hline & Abu Dhabi 2021 - WC & Plávanie/ Swimm & T1 & Bicykel/ Bik & T2 & Beh/ Run & Ciel'/ Finish \\
\hline Ciel' & Finish $\frac{\text { Korelácia/correlation }}{n}$ & $\begin{array}{c}0,713 \star \star \\
43\end{array}$ & $\begin{array}{c}0,356 \star \\
43\end{array}$ & $\begin{array}{c}\mathbf{0 , 8 9 5} \star \star \\
43\end{array}$ & $\begin{array}{c}-0,166 \\
43\end{array}$ & $\begin{array}{c}0,894 \star \star \\
43\end{array}$ & $\begin{array}{c}1,000 \\
43\end{array}$ \\
\hline Ciel'/ & $\begin{array}{l}\text { Haeundae } 2021 \text { - WC } \\
\text { Finish Korelácia/correlation } \\
\text { Barcelona } 2021-\text { EC }\end{array}$ & $\begin{array}{c}0,864 \star \star \\
30\end{array}$ & $\begin{array}{c}0,535 \star \star \\
30\end{array}$ & $\begin{array}{c}0,864 \star \star \\
30\end{array}$ & $\begin{array}{c}0,495 \star \star \\
30\end{array}$ & 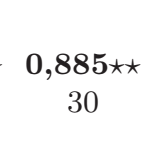 & $\begin{array}{c}1,000 \\
30\end{array}$ \\
\hline Ciel'/ & Finish $\frac{\text { Korelácia/correlation }}{\mathrm{n}}$ & $\begin{array}{c}0,714 \star \star \\
71\end{array}$ & $\begin{array}{c}0,606 \star \star \\
71\end{array}$ & $\begin{array}{c}0,771 \star \star \\
71\end{array}$ & $\begin{array}{c}0,524 \star \star \\
71\end{array}$ & $\begin{array}{c}\mathbf{0 , 8 2 0} \star \star \star \\
71\end{array}$ & $\begin{array}{c}1,000 \\
71\end{array}$ \\
\hline
\end{tabular}

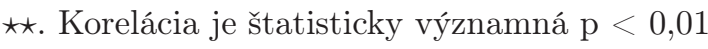

*. Korelácia je štatisticky významná p $<0,05$

Tabul'ka 8./ Table 8.

Korelácie pre olympijský triatlon ženy./Correlation for olympic triathlon women.

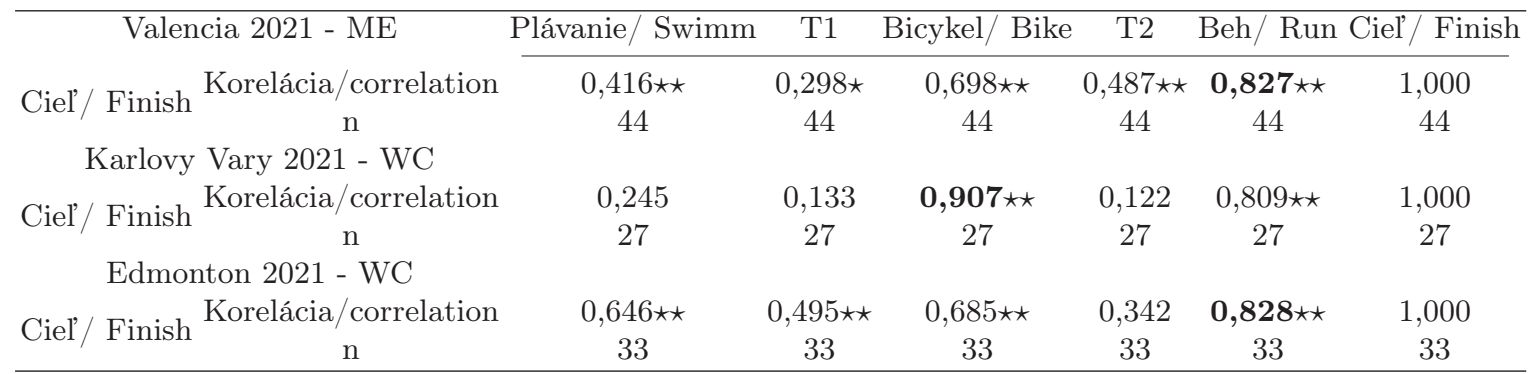

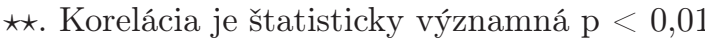

*. Korelácia je štatisticky významná $\mathrm{p}<0,05$

Tabul'ka 9./ Table 9.

Korelácie pre long triatlon ženy./ Correlation for long triathlon women.

\begin{tabular}{ccccccc}
\hline Almere 2021 - MS & Plávanie/ Swimm & T1 & Bicykel/ Bike & T2 & Beh/ Run Ciel'/ Finish \\
\cline { 2 - 7 } Ciel'/ Finish Korelácia/correlation & $0,862 \star \star$ & $0,591 \star$ & $\mathbf{0 , 8 7 9} \star \star$ & $0,602 \star$ & $0,821 \star \star$ & 1 \\
n & 16 & 16 & 16 & 16 & 16 & 16 \\
Finland 2021 - ME & & & & & & \\
Kiel'/ Finish Korelácia/correlation & $0,550 \star$ & 0,401 & $\mathbf{0 , 7 0 6} \star \star$ & 0,021 & $0,692 \star \star$ & 1,000 \\
n & 15 & 15 & 15 & 15 & 15 & 15 \\
Almere 2019 - ME & & & & & & 15 \\
Ciel'/ Finish Korelácia/correlation & 0,400 & 0,036 & $\mathbf{0 , 8 6 4 \star \star}$ & 0,419 & $0,645 \star$ & 1,000 \\
n & 11 & 11 & 11 & 11 & 11 & 11 \\
\hline
\end{tabular}

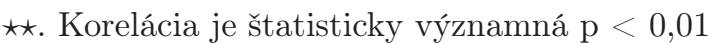

*. Korelácia je štatisticky významná p $<0,05$ 
Tabul'ka 10./ Table 10.

Korelácie pre kros triatlon ženy./ Correlation for cross triathlon women.

\begin{tabular}{|c|c|c|c|c|c|c|c|}
\hline & Paganella 2021 - ME & Plávanie/ Swimm & $\mathrm{T} 1$ & Bicykel/ Bike & $\mathrm{T} 2$ & Beh/Run & Ciel'/ Finish \\
\hline \multirow{2}{*}{ Ciel'/ } & Finish Korelácia/correlation & 0,414 & 0,409 & $0,946 \star \star$ & $0,801 \star \star$ & $0,921 \star \star$ & 1 \\
\hline & Finish n & 19 & 19 & 19 & 19 & 19 & 19 \\
\hline & El Anillo 2021 - MS & & & & & & \\
\hline \multirow{3}{*}{ Ciel'/ } & Finish Korelácia/correlation & 0,373 & 0,220 & $0,826 \star \star$ & 0,330 & $0,651 \star \star$ & 1,000 \\
\hline & Finisn $\quad n$ & 17 & 17 & 17 & 17 & 17 & 17 \\
\hline & Pontevedra 2019 - MS & & & & & & \\
\hline Ciel'/ & Finish Korelácia/correlation & 0,268 & $0,503 \star \star$ & $0,875 \star \star$ & 0,202 & $0,617 \star \star$ & 1,000 \\
\hline
\end{tabular}

$\star \star$. Korelácia je štatisticky významná $\mathrm{p}<0,01$

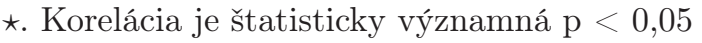

\section{Diskusia}

Celkovo sme analyzovali štyri varianty triatlonu - po tri preteky z každého, pričom sme sledovali vzt’ahy pre obe pohlavia. Celkovo sme tak obsiahli osem súborov dát. Pre šprint triatlon u mužov sme najtesnejšie vzțahy $(\mathrm{p}<0,01)$ zaznamenali dva krát pre beh $(\mathrm{R}=0,965 ; 0,849)$ a raz pre bicykel $(\mathrm{R}=0,87)$. U žien podobne dva krát pre beh $(\mathrm{R}=0,885 ; 0,820)$ a raz pre bicykel $(\mathrm{R}=0,895)$. Výsledky nepreukázali jednoznačnú dominanciu jednej disciplíny, čo potvrdzujú aj rozdielne výsledky štúdií iných autorov. Napríklad Kovářová, Jurič a Kovář (2012) zaznamenali najvýraznejší vzțah k celkovému výkonu v šprint triatlone pre beh $(\mathrm{R}=, 995 ; \mathrm{p}<0,01)$ Olaya et al., (2021) zistili najvýraznejší vzt’ah $\mathrm{k}$ celkovému výkonu pre cyklistiku ( $\mathrm{ICCa}=0,871 \mathrm{u}$ mužov a $\mathrm{ICC}=0,907 \mathrm{u}$ žien). Pre olympijský triatlon sme u mužov zaznamenali štatisticky významné $(\mathrm{p}<0,01)$ vztahy tri krát pre beh $(\mathrm{R}=0,907 ; 0,840 ; 0,964)$, u žien dva krát pre beh $(\mathrm{R}=0,827 ; 0,828)$ a raz pre cyklistiku $(\mathrm{R}=0,907)$. Fröhlich et. al., (2008) sledovali výsledky majstrovstiev sveta v olympijskom triatlone počas rokov 2003 až 2007 pričom podobne ako v našom prípade zaznamenali najvýznamnejšie korelácie pre beh $(\mathrm{R}=0.860$ (2003); 0.863 (2004); 0.951 (2005); 0.848 (2006)). Jedine v roku 2006 zaznamenali autori najvýznamnejšiu koreláciu pre cyklistiku $(\mathrm{R}=.908)$. Celkovo tak možno konštatovat', že v šprinte a olympijskom triatlone dominuje beh. Predpokladáme, že nejednoznačné výsledky sú dané meniacimi sa podmienkami počas jednotlivých sútaží. Ćím viac pretekári počas plaveckej a cyklistickej časti budú taktizovat' a pôjdu "pomaly" tým je pravdepodobnejšie, že sa rozhodne na behu. Ďalším výrazným faktorom ktorý môže ovplyvňovat' správanie sa pretekárov počas pretekov je, že počas šprintu a olympijského triatlonu je povolená jazda v zákryte. Ak je pretekár po plaveckej časti aj viac vzadu, stačí mu aby sa na cyklistike dostal do balíka. Následne počas cyklistickej časti môže taktizovat', vozit' sa vzadu, šetrit’ energiu a na bežeckej časti rozhodnút. Výsledky nemožno síce zovšeobecnit ale minimálne naznačujú, že práve táto taktický variant je často využívaný a preto ako najvýznamnejší faktor výsledku v šprint a olympijskom triatlone opakovane vychádza beh. Pre dlhý triatlon sme predpokladali, že dominantné postavenie cyklistiky. Cyklistika sa na celkovom čase podiel'a najvýraznejšie $(52,70 \%)$ a zároveň pre dlhý triatlon nie je povolená jazda v závese. Výsledky sú preto mierne prekvapivé. Zatial' čo u žien sme zaznamenali štatisticky najvýznamnejšie vzt’ahy $(\mathrm{p}<0,01)$ pre cyklistiku $(\mathrm{R}=0,879$; $0,706 ; 0,864)$ u mužov boli najvýznamnejšie vztahy vo všetkých sledovaných triatlonoch dosiahnuté pre beh $(\mathrm{R}=0,832 ; 0,772 ; 0,878)$. Predpokladáme, že to bolo spôsobené vyrovnanejším štartovým pol'om u mužov. Rozdiel medzi prvým a desiatym pretekárom v cieli bol v cyklistike $6 \%$ u mužov vs. $8 \%$ u žien. V bežeckej časti $6 \%$ u mužov vs. $4 \%$ u žien. Je teda zrejmé, že u žien sa vytvorili výraznejšie rozdiely už v cyklistickej časti. Ďalším možným vysvetlením je celková dĺžka jednotlivých úsekov pri dlhom triatlone. Bežecká časte trvá v priemere najlepším desiatim pretekárom v cieli cca 3 hod. Z pohl'adu fyziológie je beh najnáročnejší a spolu s únavou po predchádzajúcich dvoch častiach môže spôsobit, že rozdiely medzi jednotlivými pretekármi budú výraznejšie, čo sa môže odzrkadlit aj na celkovom umiestení. Kovářová, Jurič a Kovář (2012) zaznamenali pri analýze dlhého triatlonu pre beh $(\mathrm{R}=1,000 ; \mathrm{p}<0,01)$ dokonca poradie bežeckej časti $\mathrm{v}$ zhode s poradím $\mathrm{v}$ cieli. Pre terénny triatlon sme zaznamenali najvyššiu koreláciu tak u mužov $(\mathrm{R}=0,932 ; 0,896 ; 0,961 ; \mathrm{p}<0,01)$ ako aj u žien $(\mathrm{R}=0,946 ; 0,826 ; 0,875 ; \mathrm{p}<0,01)$ pre cyklistickú časté. Hoci sa cyklistika v terénnom triatlone podiel’a najvyšším percentom $(58,35 \%)$ na celkovom čase s pomedzi všetkých variant triatlonu, 
predpokladáme, že tesné korelácie sú spôsobené najmä jej náročnostou. Terénny triatlon je špecifický najmä tým, že tak cyklistická ako aj bežecká trat sú väčšinou vedené na tratiach s vel'kým prevýšením a cyklistika okrem iného zvykne obsahovat technicky vel'mi náročné pasáže. V nami sledovaných triatlonoch predstavovalo priemerné prevýšenie cyklistickej časti $1000 \mathrm{~m}$. Je preto pravdepodobné, že vynikajúci cyklisti si dokážu vybudovat’ počas cyklistickej časti rozhodujúci náskok. Hurst (2018) u mužov zaznamenal najvýznamnejšie korelácie pre cyklistiku $\left(R_{2}=0,31\right)$ a u žien pre beh $\left(R_{2}=0,46\right)$. Ked’že autor sledoval len jeden pretek výsledky mohli byt’ skreslené profilom trate, prípadne počasím. Naše výsledky naznačujú, že vyrovnanost' štartového pol'a je vyššia u mužov, čo môže spôsobovat’ rozdielne výsledky vzt’ahovej analýzy medzi pohlaviami. Treba však poukázat na fakt, že výsledky pre malý počet sledovanej vzorky nemožno zovšeobecnit'. Do d'alších výskumov odporúčame realizovat' sledovanie v priebehu niekol'kých rokov, prípadne sa zamerat' len na jednu variantu triatlonu a sledovat' viac pretekov. Taktiež odporúčame výskum rozšírit’ na kategóriu jednotlivých vekových skupín.

\section{Záver}

Ciel'om práce bolo zistit', aký je vzt’ah medzi jednotlivými disciplínami a celkovým výkonom v triatlone v roku 2021. Sledovali sme dosiahnuté časy v jednotlivých disciplínach triatlonu (plávanie, cyklistika, beh), čas strávený v prechodnej časti (T1; T2) po plávaní a cyklistike a celkový čas pretekára v cieli. Analyzovanú vzorku tvorili pretekári a pretekárky kategórie elite v štyroch rôznych variantoch triatlonu (šprint, olympijský, dlhý a terénny). Na overenie vztahov medzi jednotlivými premennými sme použili Spearmanov korelačný koeficient. Pre všetky sledované triatlony sme pozorovali štatisticky významné vztahy $(\mathrm{p}<0,05)$ pre beh, pričom najvýraznejšie sa beh podiel'a na celkovom výsledku v olympijskom $(\mathrm{R}=0,907 ; 0,840 ; 0,964)$ a dlhom triatlone mužov $(\mathrm{R}=0,832 ; 0,772 ; 0,878)$. Pre cyklistiku sme pozorovali štatisticky významné vzt’ahy $(\mathrm{p}<0,01)$ pozorovali vo všetkých sledovaných triatlonoch okrem jedného, pričom najvýraznejšie sa cyklistika podiel'ala na celkovom výsledku v terénnom triatlone mužov $(\mathrm{R}=0,932 ; 0,896 ; 0,961)$, žien $(\mathrm{R}=0,946 ; 0,826 ; 0,875)$ a v dlhom triatlone žien $(\mathrm{R}=0,879 ; 0,706 ; 0,864)$. Pre šprint triatlon mužov sme najvýznamnejšie korelácie zaznamenali dva krát pre beh $(\mathrm{R}=0,965 ; 0,849)$ a raz pre cyklistiku $(\mathrm{R}=0,873)$. U žien v šprinte, podobne ako u mužov, dominoval dva krát beh $(\mathrm{R}=0,885,0,820)$ a raz cyklistika $(\mathrm{R}=0,895)$. Pre olympijský triatlon žien sme zaznamenali najvýraznejšiu koreláciu pre beh $(\mathrm{R}=0,827 ; 0,828)$ a raz pre cyklistiku $(\mathrm{R}=0,907)$. Do športovej praxe odporúčame podl'a varianty triatlonu $\mathrm{v}$ tréningovom procese zamerat’ sa viac na disciplínu, ktorá ovplyvňuje celkový výkon najviac. V preteku odporúčame taktiku upravit’ tak, aby pretekár čo najviac šetril sily, využíval plávanie, resp. jazdu v závese (ak to pravidlá umožňujú) a snažil sa pretek rozhodnút v tej časti, ktorá determinuje celkový výkon najviac.

\section{Literatúra}

Cejuela, R., Cala, A., Pérez-Turpin, J. A., Villa, J. G., Cortell, J. M., \& Chinchilla, J. J. (2013). Temporal activity in particular segments and transitions in the olympic triathlon. Journal of human kinetics, 36(1), 87-95. https://doi.org/10.2478/hukin-2013-0009

Figueiredo, P., Marques, E. A., \& Lepers, R. (2016). Changes in Contributions of Swimming, Cycling, and Running Performances on Overall Triathlon Performance Over a 26-Year Period. Journal of strength and conditioning research, 30(9), 2406-2415. https://doi.org/10.1519/JSC. 0000000000001335

Horne, M. J. (2017) The relationship of race discipline with overall performance in sprint and standard distance triathlon age-group world championships. International Journal of Sports Science $\mathcal{G}_{3}$ Coaching, 12(6), 814-822. https://doi.org/10.1177/1747954117738878

Hurst, H. (2018). The influence of swim, cycle and run performance on overall race outcome at the off-road triathlon world championships. Journal of Science and Cycling, 6(2), 35-40. DOI: 10.28985/171231.jsc. 12

Chráska, M. (2007). Metody pedagogického výskumu. Základy kvantitativního výzkumu. Grada.

Kovářová, L., Jurič, M., \& Kovář, K. (2012). Analýza výkonu v triatlonu. Studia sportiva, 6(1), 83-92. DOI: $10.5817 /$ StS2012-1-9

Formánek, J., \& Horčic, J. (2003). Triatlon. Praha: Olympia.

Fröhlich, M., Klein, M., Pieter, A., Emrich, E., \& Gießing, J. (2008). Consequences of the Three Disciplines on the Overall Result in Olympic-distance Triathlon. International Journal of Sports Science and Engineering, 2(4), 204-210. 
Millet, G. P., \& Vleck, V. E. (2000). Physiological and biomechanical adaptations to the cycle to run transition in Olympic triathlon: review and practical recommendations for training. British journal of sports medicine, 34 (5), 384-390. DOI: 10.1136/bjsm.34.5.384

Olaya, C. J., Fernández-Sáez, J., Østerlie, O., \& Ferriz-Valero, A. (2021). Contribution of Segments to Overall Result in Elite Triathletes: Sprint Distance. International Journal of Environmental Research and Public Health, 18(16), 8422. DOI: https://doi.org/10.3390/ijerph18168422

Sousa, C. V., Aguiar, S., Olher, R. R., Cunha, R., Nikolaidis, P. T., Villiger, E., Rosemann, T., \& Knechtle, B. (2021). What Is the Best Discipline to Predict Overall Triathlon Performance? An Analysis of Sprint, Olympic, Ironman ${ }^{\circledR}$ 70.3, and Ironman ${ }^{\circledR}$ 140.6. Frontiers in physiology, 12, 654552. DOI: https://doi.org/10.3389/fphys.2021.654552

Van Schuylenbergh, R., Eynde, B. V., \& Hespel, P. (2004). Prediction of sprint triathlon performance from laboratory tests. European journal of applied physiology, 91(1), 94-99. DOI: https://doi.org/ 10.1007/s00421-003-0911-6

World Triathlon Competition Rules 2020 - Maison du Sport International Av. de Rhodanie 54 Lausanne CH -1007, Switzerland. Získané 19. Novembra 2021, z (https://www.triathlon.org/uploads/docs/ World_Triathlon_Sport_Competition_Rules_2020_201811253.pdf) - str. 100

Mgr. Lukáš Odráška, PhD.

Trnavská Univerzita v Trnave

Pedagogická fakulta

Katedra školskej pedagogiky

lukas.odraska@truni.sk 